\title{
高温ひずみ計によるクリープ損傷オンラインモニタリング システムの開発*
}

\author{
西 \\ 田秀 \\ 高*1

\section{Development of on-line Creep Monitoring System by} \\ Using New Small-Scale High Temperature Strain Gages
}

\author{
Hidetaka NISHIDA*2 \\ *2 The Chugoku Electric Power Co., Inc., \\ 3-9-1 Kagamiyama, Higashihiroshima-shi, Hiroshima, 739-0046 Japan
}

\begin{abstract}
For residual life assessments of high-temperature parts of boilers, there are problems with accuracy in the late stages of service life, including Type IV damage. During our recent testing, it became clear that the cumulative strain on the surface has a high correlation to the burst life, but, we could not find a microminiature strain gage capable of making highly accurate measurements of strain. We developed the world's first microminiature slide capacitance-type high-temperature strain gage $\left(\phi 3 \mathrm{~mm}, 600^{\circ} \mathrm{C}\right.$ capable, accuracy within $\pm 0.02 \%[ \pm 200 \mu \mathrm{S}]$, and strain range of at least $3 \%$, and developed an on-line monitoring system at the same time. We created residual life assessment software that applied omega method and the Monkman-Grant method; achieved accuracy of approximately $\pm 30 \%$, which is three times that of conventional structural, ultrasonic, and other residual life assessment techniques (30-year history); and succeeded in the development of a revolutionary technique that enables highly accurate, constant observation.
\end{abstract}

Key Words: On-Line Monitoring System, Microminiature Strain Gage, Residual Life Assessment Method, Omega Method, Monkman-Grant Method, WeldJoint, Diagnostic Technique, Creep

\section{1. 緒言}

現在全国事業用・産業用火力発電所ユニットの $80 \%$ 以上が，累積運転時間 10 万時間を超えており，20 万時間を超えたユニットも $20 \%$ 程度(1) あり, 経年化 傾向にある.

長時間運転ボイラの損傷を観察すると長手溶接部の みならず周溶接部細粒域の損傷が目立ってきている. しかしながら長手溶接部粗粒域の評価法は, 定期点検 の延長指針にも記載されているように充実している が, 周溶接細粒域は長手溶接部粗粒域の水平展開で, 例えばボイド面積率, 個数密度程度しか見当たらな い. ボイラ高温部の余寿命診断は, 夕イプIV (溶接熱 影響部細粒域に肉厚内部より発生)損傷を含めた寿命 末期の精度に課題が有る。

当社の実機模擬破壊試験で，表面の累積ひずみが破 壊寿命と高い相関があることが判明し, 余寿命診断に 有利である事を把握している。しかし，873 K 程度の 高温で数\%のひずみを数万時間高精度に測定できる超 小型ひずみ計は，高温耐絶縁性および構造上の制約か

\footnotetext{
* 原稿受付 2009 年 1 月 7 日.

*1 正員, 中国電力(株) (\$739-0046 東広島市鏡山 3-9-1).

E-mail : $455084 @$ pnet.energia.co.jp
}

ら，世界中見当たらないので，即急に開発の必要があ る.

そこで, 火力発電所ボイラ高温蒸気配管 (以下, ボイ ラ配管)のひずみを長時間計測できる「スライド式静 電容量型ボイラ配管余寿命評価用高温ひずみ計」（ $\phi 3$ $\mathrm{mm}, 873 \mathrm{~K}$ 対応，精度士0.02\%以内，ひずみ範囲 $3 \%$ 以上)を開発するとともに，本ひずみ計を使い，経年劣 化したボイラ配管の余寿命をオンラインでモニタリン グするシステムを開発した。従来は, 発電所の運転を 止めて行う定期検査の際にボイラ配管余寿命を診断し ているが, 本システムにより, 発電所を運転しながら ひずみを高精度に求めてボイラ配管余寿命の診断を行 うことができる。

今後は, 当社火力発電所に導入し, 従来の検查法と 併用しながら余寿命診断を行い，ボイラの設備信頼性 の向上を図っていきたいと考えている.

\section{2. 開 発 概 要}

$2 \cdot 1$ スライド式静電容量型ボイラ配管余寿命評価 用高温ひずみ計 本ひずみ計は図10と㧈り P1と P 2 に設置された円筒の電極 $(\mathrm{A})$ と円柱型の中心電極 (B) とから成り, P 1 と P 2 間の距離が変化すると電 極 $\mathrm{A}, \mathrm{B}$ 間に存在する静電容量 $C$ が変化する。つま 


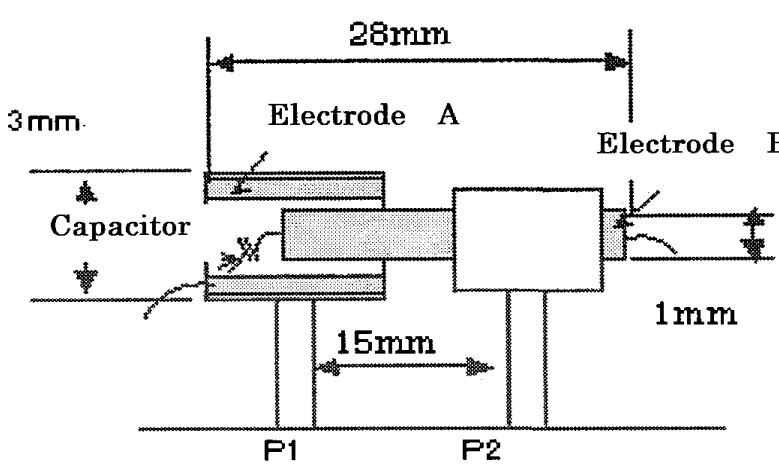

Size of StrainGage ; Dia.3m $\mathrm{m} \times$ Length $28 \mathrm{~m} \mathrm{~m}$

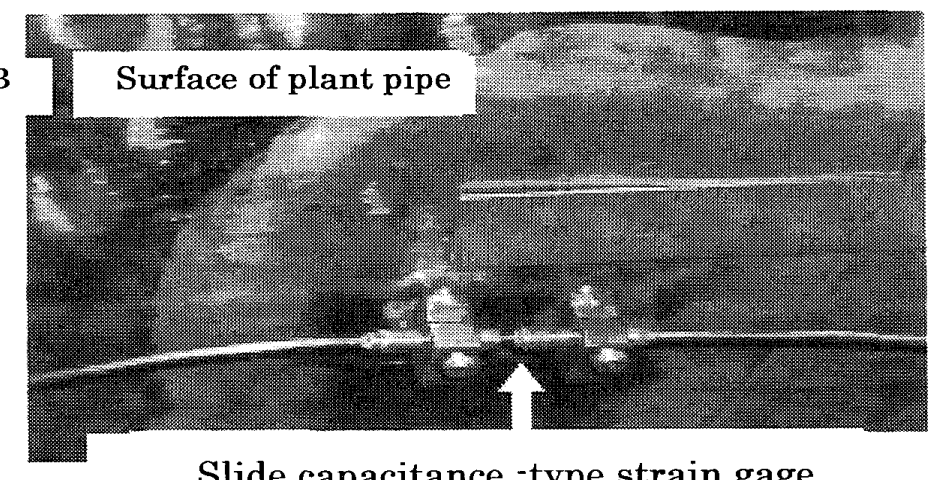

Slide capacitance -type strain gage

Fig. 1 New slide capacitance-type small-scale high temperature strain gage

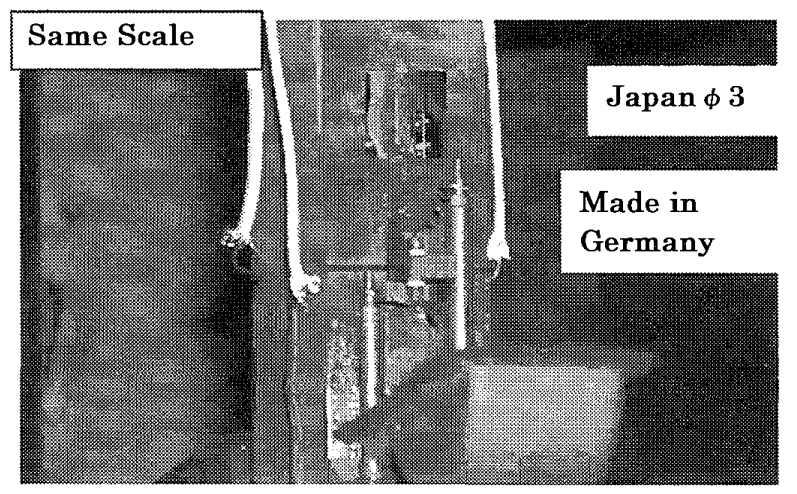

Fig. 2 Comparison of high-temperature strain gase size

り 2 枚の金属の板に交流電圧 $V$ をかけると印加電圧 に比例した電荷 $Q$ がたまる。その割合 $(Q / V)=C$ を 静電容量といい, 原理的には $C$ の変化を $Q$ の変化と して捉える。静電容量には $C=\varepsilon \times S / D$ の関係があ り, $S$ は金属板の向かい合う面積. $D$ は板間の距離. $\varepsilon$ は誘電率(定数).この静電容量から, 高精度にひず みを計測することができる。

大きさは, 高温用スライド式静電容量型では世界最 小である(図 2 参照).

火力発電所のボイラの蒸気温度を想定した $873 \mathrm{~K}$ 環境下に打いて約 2000 時間の試験を行った結果, 精 度：士0.02\%，計測限界ひずみ量：10\%を計測し，実 用可能であることを確認した。

$2 \cdot 2$ オンラインモニタリングシステム＼cjkstart計測し たひずみとボイラ配管の余寿命を関係づけるため, 余 寿命診断手法の一つであるモンクマングラント法と $\Omega$ 法(2)を適用しかつ併用するソフトウェアを開発した (図 3 参照).

当社 2 回の実験データでは, 余寿命診断精度は $\pm 30 \%$ 程度で, 30 年の歴史を持つ従来の組織や超音波 等の余寿命診断手法の 3 倍の精度を達成し, 高精度,

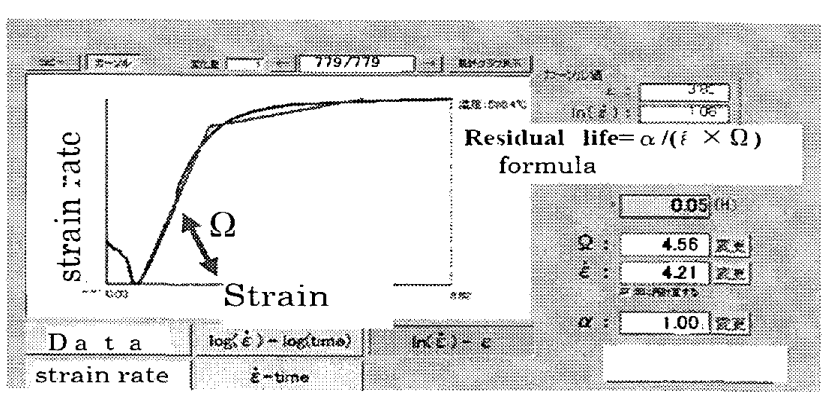

Fig. 3 New software applicable to assess residual life using the omega method

常時監視できる画期的な手法の開発に成功した。この ソフトにより高精度に余寿命を演算処理することが可 能になり，算出した余寿命のう方短い方を余寿命とし て、より安全に評価することができた。

さらに高温ひずみ計と本ソフトウェアを導入したオ ンラインモニタリングシステムを開発し， 24 時間監視 が可能になった.

\section{3. 結 言}

3 回の実機模擬破壊試験(3) を行った結果, クリープ ボイドや超音波による診断は, 結果に曖昧さが残っ た．それは引張クリープ破壞に比べて曲げ負荷がかか った場合，クリープボイドが多く発生・成長したこと による。そこでいずみによる余寿命診断手法，つまり 高温ひずみ計を使ったオンラインモニタリングシステ 厶を提案した。本方法により従来精度の 3 倍程度を達 成した。

今後は, 平成 21 年度を目途に, 同システムを当社火 力発電所に導入し, 従来の検查法と併用しながら, デ 一夕蓄積を行う。 


\section{文献}

(1) Special Issue for the 50th Anniversary of the Founding of TENPES, THERMAL and NUCLEAR POWER ENGINEERING SOCIETY, (2000), pp. 114-115.

(2) Nonaka, I., Torihara, S., Kihara, S., Umaki, H. and Maruyama, K., Evaluation of Creep Residual Life for
Modified $9 \mathrm{Cr}-1$ Mo Steel Based on Omera Method, $J$. Soc. Mat. Sci., Vol. 46, No. 4 (1997), pp. 438-442.

(3) Nishida, H., Yukami, T., Watanabe, H., Yamauchi, M., Tokiyoshi, T. and Fujita, M., Experimental Study of the Creep-Burst Mechanism on Seam-Welded High Energy Piping at Elevated Temperatures, Transaction of the Japan Society of Mechanical Engineers, Series A, Vol. 66, No. 645 (2000), pp. 946-953. 